INTERNATIONAL

CENTER FOR

PUBLIC POLICY
International Center for Public Policy

Working Paper 20-08

June 2020

Financial VAT May Improve Trade Openness

Julio López-Laborda

Guillermo Peña

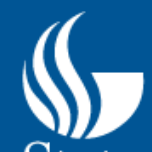

GeorgaState University
ANDREWYOUNG SCHOOL

OFPOLICYSTUDIES 



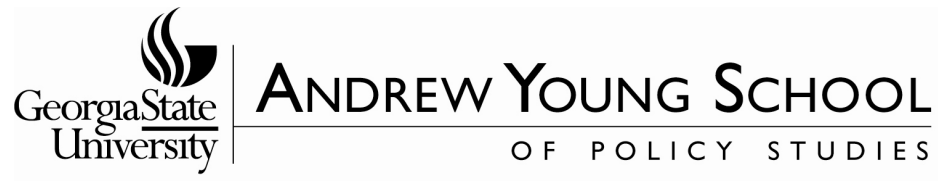

International Center for Public Policy

Working Paper 20-08

\section{Financial VAT May Improve Trade Openness}

\author{
Julio López-Laborda \\ Guillermo Peña
}

June
2020

International Center for Public Policy

Andrew Young School of Policy Studies

Georgia State University

Atlanta, Georgia 30303

United States of America

Phone: (404) 413-0235

Fax: (404) 651-4449

Email: paulbenson@gsu.edu

Website: http://icepp.gsu.edu/

Copyright 2020, the Andrew Young School of Policy Studies, Georgia State University. No part of the material protected by this copyright notice may be reproduced or utilized in any form or by any means without prior written permission from the copyright owner. 


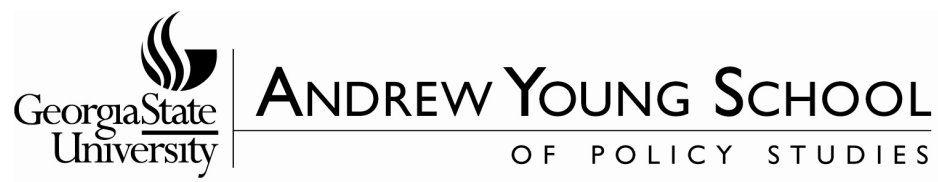

\section{International Center for Public Policy Andrew Young School of Policy Studies}

The Andrew Young School of Policy Studies was established at Georgia State University with the objective of promoting excellence in the design, implementation, and evaluation of public policy. In addition to four academic departments, including economics and public administration, the Andrew Young School houses eight leading research centers and policy programs, including the International Center for Public Policy.

The mission of the International Center for Public Policy (ICePP) at the Andrew Young School of Policy Studies is to provide academic and professional training, applied research, and technical assistance in support of sound public policy and sustainable economic growth in developing and transitional economies.

ICePP is recognized worldwide for its efforts in support of economic and public policy reforms through technical assistance and training around the world. This reputation has been built serving a diverse client base, including the World Bank, the U.S. Agency for International Development (USAID), the United Nations Development Programme (UNDP), finance ministries, government organizations, legislative bodies, and private sector institutions.

The success of ICePP reflects the breadth and depth of its in-house technical expertise. The Andrew Young School's faculty are leading experts in economics and public policy and have authored books, published in major academic and technical journals, and have extensive experience in designing and implementing technical assistance and training programs. Andrew Young School faculty have been active in policy reform in over 40 countries around the world. Our technical assistance strategy is not merely to provide technical prescriptions for policy reform, but to engage in a collaborative effort with host governments and donor agencies to identify and analyze the issues at hand, arrive at policy solutions, and implement reforms.

ICePP specializes in four broad policy areas:

- Fiscal policy (e.g., tax reforms, public expenditure reviews)

- Fiscal decentralization (e.g., reform, intergovernmental transfer systems, urban finance)

- Budgeting and fiscal management (e.g., local, performance-based, capital, and multiyear budgeting)

- Economic analysis and revenue forecasting (e.g., micro-simulation, time series forecasting)

For more information about our technical assistance activities and training programs, please visit our website at icepp.gsu.edu or contact us at paulbenson@gsu.edu. 


\title{
Financial VAT May Improve Trade Openness
}

\author{
Julio López-Laborda and Guillermo Peña ${ }^{1}$
}

June 2020

\begin{abstract}
This paper theoretically and empirically analyzes the influence on the rate of trade openness of the taxation of financial services under VAT. The empirical analysis is carried out using data from the OECD and 36 European Union countries for the period 1961-2012. Dynamic panel data techniques are used, concretely the GMM System, and an unbalanced panel is handled. The results corroborate that financial VAT, and in particular the "option-to-tax" method applied by some countries in the European Union, have a positive impact on a country's rate of trade openness.
\end{abstract}

Key words: financial VAT, trade openness, panel data

JEL classification: H25, H21, E62, F14

Keywords: municipal finance, revenue capacity, expenditure needs, fiscal gap

\footnotetext{
${ }^{1}$ Department of Public Economics, University of Zaragoza, Spain
} 


\section{Introduction}

Although in some countries financial services are levied with indirect taxes, in most countries these services are exempt from VAT. This exemption has several consequences for the economy. Those most studied relate to efficiency, as the exemption causes several distortions, mainly due to irrecoverable VAT for businesses. ${ }^{1}$ Furthermore, there are other distortions. As far as equity is concerned, and to the extent that financial services are consumed to a greater proportion by wealthier individuals, the exemption increases inequality in income distribution (Huizinga, 2002; López-Laborda and Peña, 2017a). Tax revenue is also affected by the exemption, with no consensus among scholars concerning the impact. The results of a hypothetical VAT collection on financial services range from 6 to 15 billion euros for Europe (Huizinga, 2002; European Commission, 2011; Lockwood, 2011).

One way the exemption affects efficiency is its impact on trade openness, because financial services are under-taxed services for households and, as a kind of non-traded good, this undertaxation discourages the consumption of correctly-taxed goods, as is the case of all traded goods, which are taxed by the general VAT rate. Therefore, removing the VAT exemption of financial services and taxing them at a positive tax rate could reduce disincentives for traded services, and therefore, trade openness would increase. The aim of this paper is to empirically test whether applying indirect taxes to financial services, and applying VAT in particular, positively affects the rate of trade openness.

\footnotetext{
${ }^{1}$ For a detailed review of the economic distortions of the exemption of financial services on VAT, see López-Laborda and Peña (2018).
} 
The literature has proposed several methods for taxing financial services, some of which are currently applied in international practice. Table 1 shows the main methods applied around the world in different countries.

The "zero rate" method consists of establishing a VAT rate of 0 percent on financial services, allowing financial institutions to claim input VAT. The "exemption with partial input credits" method, also known as "partial income recovery", is the intermediate method between exemption and zero-rating, where a percentage of the input VAT is allowed for crediting. In the method of "taxation of fees and commissions", there is a mandatory taxation of all the explicit fees and charges of financial services and a recoverable input VAT. The "option-to-tax" method allows financial entities the possibility of charging VAT on financial services or not, applying the tax on the interest margin, and fees and commissions, or only on the latter. "Net operating income" and "gross interest" methods take net operating income and gross lending interest, respectively, as the tax basis for VAT. In the "addition" method, the tax is calculated by considering the sum of wages, rents, interests, and net profits as the tax base. In the "subtraction" method, the tax base is the difference between revenues and purchases, being both financial and non-financial. The "separate taxes" method consists of a new type of tax on financial services distinct from general VAT; a specific example is the Financial Activities Tax (FAT), which also includes aspects of the addition method. These last five methods do not allow financial entities to credit their input VAT. $^{2}$

${ }^{2}$ For a more in-depth description and analysis of the various methods, see López-Laborda and Peña (2017b, 2018). 


\begin{tabular}{|c|c|c|c|}
\hline Method & Countries where applied & Method & Countries where applied \\
\hline & & Net & \\
\hline Zero-rating & $\begin{array}{c}\text { Quebec (up to 2013), New Zealand (since 2005; } \\
\text { Merrill 2011), }\end{array}$ & $\begin{array}{l}\text { operating } \\
\text { income }\end{array}$ & Mexico (since 1992; Schatan 2003) \\
\hline
\end{tabular}

\begin{tabular}{|c|c|c|c|}
\hline $\begin{array}{l}\text { Exemption } \\
\text { with partial } \\
\text { input credits }\end{array}$ & $\begin{array}{c}\text { Australia (since 2000; De la Feria and Walpole } \\
\text { 2009), Singapore (since 1994; Jenkins and } \\
\text { Khadka 1998), Malaysia (since 2015; IMF } \\
\text { 2015) }\end{array}$ & $\begin{array}{l}\text { Subtraction } \\
\text { method }\end{array}$ & $\begin{array}{l}\text { Italy (since 1998; Keen et al. 2010), proposed in } \\
\text { Japan to be established in 1950, but rejected (De la } \\
\text { Feria and Krever 2012), also proposed in Canada on } \\
\text { 1987(Schenk. 2009), and in the Philippines (Xu and } \\
\text { Krever 2016) proposed on 2000, but abandoned before } \\
\text { implementing }\end{array}$ \\
\hline $\begin{array}{l}\text { Taxing fee- } \\
\text { based } \\
\text { services }\end{array}$ & $\begin{array}{l}\text { Australia, Singapore, South Africa (since 1996; } \\
\text { Merrill 2011), Malaysia, the Philippines (since } \\
\text { 1988), India (since 1994; Deloitte 2013), China } \\
\text { (since 1994; Owens 2014), Korea (since 1982; } \\
\text { MSF 2012), Belgium (1971-1977; Ernst and } \\
\text { Young 2009), Slovenia (since March 2013, PKF } \\
\text { 2014), Andorra (since 2013), Gahana (since } \\
\text { 2015; PWC 2015), Mexico (since 1980; Schatan } \\
\text { 2003), Thailand (since 1992; BOI 2016), } \\
\text { Taiwan }\end{array}$ & $\begin{array}{l}\text { Separate } \\
\text { taxes }\end{array}$ & $\begin{array}{l}\text { Quebec, Israel (since 1981; Gillis 1987), France (since } \\
\text { 1968; Pons 2006), Denmark, Italy, Andorra (from } \\
\text { June } 2002 \text { to 2013, as a sales equalization tax; } \\
\text { ABA 2010), China (from } 1994 \text { (Owens 2014) up to } \\
1 \text { May 2016 (KPMG 2016)), India (since 1994 } \\
\text { (Deloitte 2013), proposed under GST in 2016, but } \\
\text { postponed until 2017), the Philippines (since 1946; } \\
\text { except for the year 2003 when it was taxed under } \\
\text { VAT, ZGLO 2006), Taiwan (since } 1 \text { April 1986; } \\
\text { ROC 2016), Thailand, Iceland and Korea }\end{array}$ \\
\hline $\begin{array}{l}\text { Option to } \\
\operatorname{tax}\end{array}$ & $\begin{array}{l}\text { Option to tax only fees (partial taxation): } \\
\text { Belgium (since 1978), Lithuania (since } 1 \text { May } \\
\text { 2004), France (since 1979) } \\
\text { Option to tax fees and margin (full taxation): } \\
\text { Austria (since } 1997 \text { with retroactive effect), } \\
\text { Estoniai (since 2002), Germany (since 1968) } \\
\text { Source: Ernst and Young (2009) }\end{array}$ & $\begin{array}{l}\text { Addition } \\
\text { method }\end{array}$ & $\begin{array}{l}\text { Quebec, Michigan (since 1953; De la Feria and } \\
\text { Krever 2012), France (since 1979; Pons 2006), Israel } \\
\text { (since 1976; Gillis 1987), Denmark (since 1988; } \\
\text { Moller and Hjerrild 2013) }\end{array}$ \\
\hline $\begin{array}{l}\text { Taxation of } \\
\text { gross } \\
\text { interest }\end{array}$ & $\begin{array}{c}\text { Argentina (since 1992; Zee 2004). Proxy taxes } \\
\text { (Burns 2007): China (since 1994; Owens 2014), } \\
\text { on VAT since 1 May 2016; KPMG 2016), the } \\
\text { Philippines (since 1946; ZGLO 2006), Taiwan } \\
\text { (since April 1986, ROC 2016), Thailand and } \\
\text { Korea }\end{array}$ & $\begin{array}{l}\text { Financial } \\
\text { Activities } \\
\quad \text { Tax }\end{array}$ & Iceland (since 2012; Keen et al. 2016) \\
\hline
\end{tabular}

As Guttmann and Richards (2006) state, the literature on the determinants of trade openness is scarce, in spite of such seminal papers as Alesina and Wacziarg (1998). These authors include geographical variables, the tax import ratio, the terms of trade, and public expenditure to explain trade openness. Subsequently, there have been new contributions to the topic. Concretely, there are advances in the study of geographical and commercial variables, such as Hau (1999), Alcalá and Ciccone (2004), Guttmann and Richards (2006), Ram (2009) and Marjit et al. (2014). Other 
authors incorporate financial depth as a determinant, such as Svaleryda and Vlachos (2002) or Aizenman and Noy (2009). Finally, some authors study the influence of consumption or the public sector size on the trade openness rate (Garen and Trask, 2005; Benarroch and Pandey, 2008, 2012; Benarroch and Pandey, 2012, and Jetter and Parmeter, 2015). Other papers also study the cointegration of the dependent variable with other variables, such as energy consumption (Nasreen and Anwar, 2014), or look for determinants of other variables distinct from but relating to trade openness, such as international competition (Chang et al., 2009).

The literature on the determinants of the rate of trade openness has not yet analyzed the impact of financial VAT on trade openness. ${ }^{3}$ In order to analyze this, we manage an unbalanced data panel of 36 countries for the period 1961-2012. The selected countries are developed and developing countries of the EU (27) and the OECD, with the exception of Switzerland, Cyprus, Romania and Malta. Due to the temporal dependence of the data on the dependent variable (trade openness rate), a dynamic panel data is estimated, following the Generalized Method of Moments (GMM) in two steps.

The paper is divided into five sections. Section 2 develops the framework that theoretically establishes the influence of financial VAT on the rate of trade openness. Section 3 proposes the specification of the econometric model and the variables to be incorporated. Section 4 estimates the econometric model that analyzes the impact of financial VAT on trade openness and discusses the results. Our estimates suggest, first, that financial VAT, and in particular the "option-to-tax" method applied by some countries in the European Union, has a positive impact

\footnotetext{
${ }^{3}$ At present, as far as we know, the impact of financial VAT on any variable has not yet been studied with real data and econometric techniques, except for the impact of this tax on the size of the financial sector (López-Laborda and Peña, 2017c) and on income distribution (López-Laborda and Peña, 2017a).
} 
on a country's rate of trade openness, and second, that the "separate taxes" do not appear to have a significant effect on trade openness.

\section{Conceptual Framework}

In this section, we propose a theoretical framework for analyzing the effects of the financial VAT on trade openness, based on Feldstein and Krugman (1990), and assuming full passthrough of VAT to prices (Benedek et al, 2019). We consider a country that produces and consumes an exported $\operatorname{good} \boldsymbol{X}$, an imported $\operatorname{good} \boldsymbol{M}$, and a non-traded $\operatorname{good} \boldsymbol{N}$. The country is assumed to be small on world goods markets, so that it can trade $\boldsymbol{X}$ for $\boldsymbol{M}$ at a fixed relative price. The rate of trade openness of the country is defined as the sum of exports and imports over total GDP.

The country applies a typical VAT, with tax refund on exports and taxation on imports, so that imports and exports are both reduced in the same proportion by the application of the VAT, which allows us to aggregate $\boldsymbol{X}$ and $\boldsymbol{M}$ into a composite traded good $\boldsymbol{T}$. Non-traded good is exempted from VAT. As we will see below, the exemption, which does not allow input VAT to be credited, results in an under-taxation of the non-traded sector compared to the traded sector, which encourages an increase in non-tradable consumption and production while reducing the size of the trading sector, and therefore a decrease in the rate of trade openness would be expected.

We can consider financial services to be more similar to a non-traded than to a traded service, as those services are currently more often provided in physical branch offices than on the Internet. As shown by Freund and Weinhold (2002), while the Internet has improved trading with many services, this result is stronger when excluding some services as financial intermediation. Nonetheless, this effect could currently be lessening, since the development of regulation in the 
main trading conduits is reducing the trading costs of financial services (Miroudot, Sauvage, and Shepherd, 2013). While some authors, as Krugman (1991, p. 65) states, consider that "[s]ome services, however, especially in the financial sector, can be traded", the literature has traditionally considered them non-traded services (Benigno and Fornaro, 2014). Indeed, the consumption of financial services reached 76.7 percent of the final demand for these services in 2015 in Spain, while exports only reached 23.3 percent. ${ }^{4}$ The export share of financial services is significantly lower than that of traditionally traded products: textile products reach a share of 46.7 percent and motor vehicles, 65.3 percent.

Next, we analyze the expected differences in trade between the following five scenarios concerning financial VAT, representative of the various methods applied in international practice as shown in Table 1: exemption, zero-rate, separate taxes, option to tax, and the taxation of financial services under VAT with a positive tax rate.

First, the inefficiency derived from the exemption is analyzed. Considering $p_{T}$ are the prices of the traded goods in the country, $p_{N}$ are the prices of the non-traded goods (financial services) in this country, $t^{G}$ is the general VAT rate, $t^{f}$ is the tax rate or the VAT applied to financial services, and $0<\gamma<1$ is the percentage of the traded goods that are used as input in non-traded goods, and assuming the tax collection is higher than the irrecoverable VAT; we can represent the relative price of traded to non-traded goods as follows:

(1) $\frac{\left(1+t^{G}\right) p_{T}}{p_{N}+\gamma t^{G} \cdot p_{T}}>\frac{p_{T}}{p_{N}} \Rightarrow T_{e}<T_{*}$

\footnotetext{
${ }^{4}$ Data from the Input-Output Table for basic prices from the Spanish National Institute for Statistics (INE, 2015). Accessed on 23 April 2020.
} 
This expression shows that the exemption (identified by sub-index $e$ ) reduces the size of the tradable sector, $T_{e}$, by increasing its price relative to non-traded goods, with respect to the general method of taxation in VAT, $\boldsymbol{T}_{\boldsymbol{*}}$. The next expression compares the exemption and "zerorate" cases:

$$
\frac{\left(1+t^{G}\right) p_{T}}{p_{N}}>\frac{\left(1+t^{G}\right) p_{T}}{p_{N}+y t^{G} \cdot p_{T}} \Rightarrow T_{z r}<T_{e}
$$

If "zero-rate" is applied to financial services, non-traded goods are not taxed, but the input VAT is refunded. Therefore, the tax levy and the price of these services is lower than in a case where the non-traded sector cannot deduct input VAT, which is the case for the exemption. Hence, the "zero-rate" method would further increase the price of traded goods relative to non-traded ones, discouraging traded goods, $T_{z r}$, more than the exemption method.

We now compare the exemption method and "separate taxation". The latter applies a positive tax rate on financial services but, as it is a different tax from VAT, the VAT chain is also broken as in the exemption method. The relative price of traded to non-traded goods is then as follows:

$$
\frac{\left(1+t^{G}\right) p_{T}}{\left(1+t^{S}\right) p_{N}+\gamma t^{G} \cdot p_{T}}<\frac{\left(1+t^{G}\right) p_{T}}{p_{N}+\gamma t^{G} \cdot p_{T}} \Rightarrow T_{s t}>T_{e}
$$

So, the tradable sector is encouraged with "separate taxes", $T_{s t}$, compared to the exemption or "zero-rate" methods.

The fourth method we will discuss is financial VAT with positive tax rate:

$$
\frac{\left(1+t^{G}\right) p_{T}}{\left(1+t^{f}\right) p_{N}}<\frac{\left(1+t^{G}\right) p_{T}}{p_{N}+\gamma t^{G} \cdot p_{T}} \Rightarrow T_{f t}>T_{e}
$$


Assuming that the irrecoverable input VAT is lower than the collected financial VAT, we can see that the relative price is lower with the full financial VAT method than with the exemption method and therefore the tradable sector will be incentivized in the first case, $T_{f t}$, compared to the exemption method.

It is worth noting that, if $t^{G}=t^{f}$, then $\left(1+t^{G}\right) p_{T} /\left(1+t^{f}\right) p_{N}=p_{T} / p_{N} \Rightarrow T_{f t}=T_{*}$. In this case, the following will be fulfilled:

$$
T_{z r}<T_{e}<T_{*}=T_{f t}<T_{s t}
$$

Consequently, the method of separate taxation could encourage an inefficiently high tradable sector.

And finally, the "option-to-tax" method is considered. This method allows financial entities to opt between the exemption and the taxation of financial services in VAT with a positive tax rate and the deduction of input VAT:

$$
\frac{\left(1+t^{G}\right) p_{T}}{\left(1+\alpha t^{f}\right) p_{N}+(1-\alpha) \gamma t^{G} \cdot p_{T}} \leq \frac{\left(1+t^{G}\right) p_{T}}{p_{N}+\gamma t^{G} \cdot p_{T}} \Rightarrow T_{o t} \geq T_{e}
$$

Where $\mathbf{0} \leq \boldsymbol{\alpha} \leq \mathbf{1}$ is the proportion of businesses from country A that opt to tax. The aggregate results of this method are between those of full taxation (for $\alpha=1$, expression 6 equates expression 4) and those of the exemption method (for $\alpha=0$, expression 6 equates expression 3 ). In short, if financial services are considered as non-traded services, the results summarized in (5) suggest that financial VAT can enhance the size of the tradable sector, at the expense of the nontradable sector, and hence increase the level of trade openness. According to our theoretical analysis, the most suitable methods seem to be full taxation and "option-to-tax". 


\section{Specifications}

According to the theoretical results obtained in the previous section, our objective is to empirically test whether VAT on financial services positively affects the degree of trade openness of countries.

Like Chang et al. (2009) and Marjit et al. (2014), we will estimate a model that applies the System GMM method for dynamic panel data (Arellano and Bover, 1995, and Blundell and Bond, 1998). The specification is as follows:

(7) openness $_{i t}=\gamma^{*}$ openness $s_{i t-1}+\beta_{T} T+\beta \mathbf{x}_{i t}+a+c_{t}+\varepsilon_{i t}$

Where openness $s_{i t}$ is a variable that reflects, in percentage, the trade openness rate of the country $i$ in year $t$. This variable is the sum of exports and imports of goods, divided by the value of GDP, in US dollars and current prices. The variable openness ${ }_{i t-1}$ is the first lag of the endogenous variable and $\gamma$ is its coefficient. $\boldsymbol{T}$ is our vector of interest variables (if financial services are subject to VAT, and, if so, the method and the tax rate applied), $\mathbf{x}_{i t}$ are the control variables, $\beta$ are the coefficients, $a$ is the constant, $c_{t}$ is the trend, and $\varepsilon_{i t}$ is the disturbance term.

Two complementary specifications are formulated, which differ in the variables of interest they incorporate. The first specification uses $f v a t * f r$ and separate $* f r$ as interest variables. The first is the interaction of $f v a t$, a binary variable taking the value 1 if financial services are subject to VAT according to Table 1 (excluding FAT and separate taxes), and 0 otherwise; with $f r$, the financial services tax rate applied as a percentage. The second is the interaction of $f r$ with separate, a binary variable taking the value 1 if financial services are subject to a separate tax, and 0 otherwise. As seen in Section 2, a country with financial VAT would have a higher rate of 
trade openness than with the exemption, because it would avoid discouraging traded goods compared to non-traded goods such as financial services. In addition, the expected effect will be greater as the financial VAT rate approaches the general VAT rate.

In the second specification, we focus on determining the effect on the ratio of trade openness of the financial VAT method most used by the countries in the sample, which is the "option-to-tax" method established by the European Union (EU). Article 137(1)(a) of the VAT Directive currently in force allows EU Member States to introduce an option-to-tax financial services. In the EU, the exemption is generally applied, but since 1978 several countries, such as Austria, Belgium, Estonia, France, Germany and Lithuania, have successively introduced the option-totax system. The "option-to-tax" method allows financial entities to opt to levy VAT on financial services. If an entity decides not to levy VAT, the exemption is applied. If it opts to tax, then financial services are subject to VAT using the VAT method chosen by the country where the financial services provider is established. In this way, each financial entity chooses the most profitable option depending on the volume of input VAT that the company incurs. This method is designed for financial entities that provide services to businesses and apply for a large amount of deductible input VAT (López-Laborda and Peña, 2017b).

This specification uses $O 2 T^{*} f r$, alter*fr and separate* $f r$ as variables of interest. The first is the interaction of the financial tax rate, $f r$, and $O 2 T$, a dummy variable that reflects whether a country applies (value 1) or not (value 0 ) the "option-to-tax" method. The second variable of interest is the interaction of $f r$ with alter, a dummy that reflects whether a country applies (value 1) or not (value 0) financial VAT with a method other than the "option-to-tax". ${ }^{5}$

\footnotetext{
${ }^{5}$ If any data is zero in both $f V A T$ and separate variables, it means that either the country exempted financial services from VAT that year, or the country was not taxing VAT at that time (e.g. US). In the case of France, where financial
} 
The following variables are used as controls in both specifications, according to the literature on trade openness (see Table 2). The variables related with the demand side are $g d p p c, c p c$ and electricity. The gdppc variable is the logarithm of GDP per capita, lagged one period to avoid simultaneity and endogeneity problems. Per capita capital, incorporated through $c p c$ variable, is measured by gross investment divided by the country's population, expressed in thousands of millions of dollars and considering investment as the purchase of fixed assets plus net changes in stock. Electricity production, net from energy losses occurred during transformation, distribution and consumption, lagged one year, is measured in $\mathrm{kW}$ hour per capita by the electricity variable. The following variables reflect public affairs. The size of the public sector is incorporated by the psize variable, measured by public expenditure over GDP, considering public expenditure such as government payments for operational activities for the provision of goods and services, including workers' remuneration (as wages and salaries), interests and subsidies, donations, social benefits and other costs like income and dividends, according to the World Bank. A country's public surplus is controlled by the surplus variable, which is the percentage of surplus over the total GDP. Finally, the experience variable reflects the total years since the entry into force of VAT.

Institutional variables are also included in the specifications. Political stability is considered with stability, a variable that captures the probability expectations of a destabilization of the government. The second variable measures the gross secondary school enrolment rate, which is the total number of secondary school students divided by the total number of persons of secondary school age. Language is an indicator of institutional development, and measures the

VAT and a separate tax were in force simultaneously for a while, we have considered it as financial VAT during that period. 
presence of at least a significant minority of the population whose mother tongue is one of Europe's five main languages (English, French, German, Spanish and Russian). Infrastructures are considered through the mobiles variable, which measures mobile phone lines per 100 people.

The models also include some geographical variables. The local variable takes the value 0 if the country is an island, and otherwise, is equal to the result of dividing one by the number of countries that have a common border. ${ }^{6}$ The population is incorporated by the population variable, which is the de facto population estimated at the middle of the year. The density variable reflects the de facto population divided by the surface area of the country. We also control by the area variable, which is the size of a country measured by its area.

Finally, financial and trading variables are also incorporated. The size of the financial sector is included through the $f$ size variable, which is the percentage of national private credit provided by the financial sector over total GDP, lagged one year. Inflation is the rate of growth of the price index. Financial openness is measured by fopenness, which is the sum of the capital and current accounts of the balance of payments, with a lag of one year. The terms of trade adjustment, TOT, is the level of import minus export of goods and services.

All variables have been obtained from the World Bank database (World Bank, 2018), with the exceptions of language, local, experience, fr, fvat, O2T, alter and separate, all created by the authors. The expected signs for the coefficients of each variable are shown in Table 2. We use panel data, with information from the years 1961 to 2012 from 36 countries: all European Union

\footnotetext{
${ }^{6}$ Other location variables have been used, such as the mean distance to France, USA and Japan, but we obtained worse results in the estimates of the models.
} 
countries (27) and the OECD, with the exceptions of Switzerland, Cyprus, Romania and Malta.

Table 3 contains the main descriptive statistics of the variables used in the estimates.

Table 2. Expected Signs

\begin{tabular}{|c|c|c|c|c|c|}
\hline Variable & $\begin{array}{l}\text { Exp. } \\
\text { sign }\end{array}$ & Literature & Variable & $\begin{array}{l}\text { Exp. } \\
\text { sign }\end{array}$ & Literature \\
\hline$f v a t * f r$ & $(+)$ & $\begin{array}{l}\text { Feldstein and Krugman } \\
(1990)\end{array}$ & second & $(+)$ & Chang et al. (2009). \\
\hline$O 2 T^{*} f r$ & $(+)$ & By the authors & language & $(+)$ & Alcalá and Ciccone (2004) \\
\hline alter $* f r$ & $(+)$ & By the authors & mobiles & $(+)$ & Chang et al. (2009) \\
\hline separate*fr & $(+)$ & By the authors & local & $(+/-)$ & $\begin{array}{l}\text { (+): Chang et al. (2009), (-): } \\
\text { Guttmann and Richards (2006) } \\
(+) \cdot \operatorname{Ram}(2009)(-) \cdot \text { Alesina and }\end{array}$ \\
\hline$g d p p c$ & $(-)$ & $\begin{array}{l}\text { Guttman and Richards } \\
\text { (2004) }\end{array}$ & pop & $(+/-)$ & $\begin{array}{c}\text { Wacziarg (1998), Alcalá and Ciccone } \\
\text { (2004), Guttman and Richards } \\
\text { (2004). }\end{array}$ \\
\hline$c p c$ & $(+)$ & Marjit et al. (2014) & density & $(+/-)$ & $\begin{array}{c}\text { Ram (2009): theoretically }(-), \\
\text { empirically }(+)\end{array}$ \\
\hline electricity & $(+)$ & Nasreen and Anwar (2014) & area & $(-)$ & $\begin{array}{l}\text { Alesina and Wacziarg (1998), and } \\
\text { Guttman and Richards (2004). }\end{array}$ \\
\hline psize & $(+)$ & $\begin{array}{c}\text { Alesina and Wacziarg } \\
\text { (1998), Rodrik (1998), } \\
\text { Garen and Trask (2005) and } \\
\text { Ram (2009) }\end{array}$ & fsize & $(+)$ & Chang et al. (2009) \\
\hline surplus & $(+)$ & Aizenman and Noy (2009) & inflation & $(0 /-)$ & $\begin{array}{c}\text { Chang et al. (2009). Aizenman and } \\
\text { Noy (2009) }\end{array}$ \\
\hline experience & $(+)$ & Alesina and Wacziarg (1998) & fopen & $(+)$ & Aizenman and Noy (2009) \\
\hline stability & $(+/-)$ & $\begin{array}{l}(+) \text { : Hau (1999), (-): } \\
\text { Aizenman and Noy (2009), } \\
\text { Marjit et al. (2014). }\end{array}$ & TOT & $(-)$ & Camagni (2002) \\
\hline
\end{tabular}


Table 3. Descriptive Statistics

\begin{tabular}{|c|c|c|c|c|c|c|c|}
\hline Variable & $\begin{array}{c}\text { No } \\
\text { observations }\end{array}$ & Mean & $\begin{array}{l}\text { Standard } \\
\text { Deviation }\end{array}$ & Minimum & Maximum & Skewness & Kurtosis \\
\hline openness (\%) & 1583 & 54.593 & 32.235 & 6.816 & 184.901 & 1.274 & 4.616 \\
\hline$g d p p c(\ln )$ & 1611 & 8.909 & 1.267 & 4.516 & 11.627 & -0.395 & 2.561 \\
\hline psize (\%) & 1133 & 31.556 & 11.563 & 1.148 & 88.608 & 0.143 & 4.546 \\
\hline $\operatorname{cpc}(\$)$ & 1527 & 0.000 & 0.000 & 0.000 & 0.000 & 4.726 & 27.989 \\
\hline fopen (\$) & 252 & $-1.32 \mathrm{E}+10$ & $1.15 \mathrm{E}+11$ & $-8.09 \mathrm{E}+11$ & $2.97 \mathrm{E}+11$ & -3.859 & 26.173 \\
\hline $\begin{array}{c}\operatorname{density}\left(\mathrm{km}^{2}\right. \\
p c)\end{array}$ & 1794 & 105.496 & 104.458 & 1.354 & 500.545 & 1.484 & 4.762 \\
\hline local (0-1) & 1689 & 0.370 & 0.325 & 0 & 1 & 1.088 & 2.875 \\
\hline surplus (\%) & 575 & -1.546 & 4.351 & -29.420 & 20.010 & 0.397 & 9.273 \\
\hline stability & 504 & 0.704 & 0.641 & -1.623 & 1.668 & -1.429 & 5.030 \\
\hline mobiles & 1848 & 25.750 & 43.299 & 0 & 172.322 & 1.450 & 3.643 \\
\hline inflation (\%) & 1518 & 11.162 & 39.335 & -4.480 & 1058.374 & 16.569 & 374.716 \\
\hline TOT (\$) & 1527 & $7.04 \mathrm{E}+11$ & $6.09 \mathrm{E}+12$ & $-3.58 \mathrm{E}+13$ & $6.97 \mathrm{E}+13$ & 7.307 & 74.094 \\
\hline fvat $(0-1)$ & 1872 & 0.115 & 0.319 & 0 & 1 & 2.415 & 6.838 \\
\hline$O 2 T(0-1)$ & 1872 & 0.080 & 0.271 & 0 & 1 & 3.098 & 10.604 \\
\hline alter (0-1) & 1872 & 0.035 & 0.183 & 0 & 1 & 5.061 & 26.646 \\
\hline $\begin{array}{c}\text { separate }(0- \\
1)\end{array}$ & 1872 & 0.056 & 0.229 & 0 & 1 & 3.881 & 16.059 \\
\hline$f r(\%)$ & 1829 & 2.6 & 6.3 & 0 & 25 & 2.237 & 6.409 \\
\hline
\end{tabular}

\section{Estimates and Results}

To avoid problems of multicollinearity, the correlation matrix is analyzed and the VIF test is applied and, as a consequence, the variables fsize, electricity, area, population, language, experience and second are initially eliminated. Next, due to the high temporal period, unit root tests are applied to the dependent variable, in particular Im-Pesaran-Shin and Phillips-Perron. These tests indicate a problem of unit root. Therefore, a time trend has been incorporated into the model (Phillips and Perron, 1988). The GMM System is applied to the two specifications 
formulated in Section 3, and the methodology is the same for estimating both models. First, each model is estimated taking all non-correlated variables into account. Once this is done, the Sargan test (over-identification of the instruments) and Arellano and Bond test (non-autocorrelation of residues) are applied. The Sargan test assumes the validity of the applied instruments as null hypothesis. In this first step, no good econometric properties are obtained, so better models are needed.

Second, we sequentially eliminate the non-significant variables from previous models until we obtain estimates in which the validity of the instruments and non-autocorrelation of the residues are corroborated. In these resulting models, the residuals are obtained by a WC-robust estimator derived by Windmeijer (2005), which is a robust and bias-corrected estimator for two-step VCEs (variance-covariance matrix estimators). This gives final Models I and II shown in Table 4.

A positive and statistically significant impact in trade openness is obtained for the coefficients of financial VAT ( $f v a t * f r$, Model I) and of taxation through the "option-to-tax" method (O2T* $f r$, Model II), as predicted by our theoretical framework. A 1-percent increase in the financial rate of VAT in a country increases the short-term rate of trade openness by 2.57 percent, while a 1percent increase in the financial rate through the application of the "option-to-tax" method raises the trade openness rate by 2.74 percent in the short term. However, the taxation of the financial services by means of an out-of-VAT tax, which does not allow the full credit of input VAT, as well as financial VAT types other than the "option-to-tax" method, do not seem to have any significant influence on the rate of trade openness, as shown by the low significance of the coefficient associated with these variables. 
Table 4. Estimates Results

\begin{tabular}{|c|c|c|c|c|c|c|}
\hline \multirow{2}{*}{$\begin{array}{c}\text { Dependent variable: } \\
\text { openness }\end{array}$} & \multicolumn{3}{|c|}{ Model I } & \multicolumn{3}{|c|}{ Model II } \\
\hline & Coeff. & Std. e. & p-value & Coeff. & Std. e. & p-value \\
\hline openness $t-1$ & 0.726 & 0.088 & 0 & 0.683 & 0.112 & 0 \\
\hline trend & 1.854 & 0.57 & 0.001 & 1.801 & 0.549 & 0.001 \\
\hline$g d p p c$ & -15.420 & 5.24 & 0.003 & -16.438 & 4.516 & 0 \\
\hline surplus & 0.784 & 0.342 & 0.022 & 0.684 & 0.397 & 0.085 \\
\hline stability & 2.072 & 3.206 & 0.518 & 0.654 & 2.985 & 0.827 \\
\hline inflation & & & & 0.305 & 0.373 & 0.413 \\
\hline TOT & $-2.88 \mathrm{E}-13$ & $1.32 \mathrm{E}-13$ & 0.03 & $\begin{array}{c}-3.67 \mathrm{E}- \\
13\end{array}$ & $1.10 \mathrm{E}-13$ & 0.001 \\
\hline$f v a t^{*} f r$ & 2.572 & 1.273 & 0.043 & & & \\
\hline$O 2 T^{*} f r$ & & & & 2.736 & 1.557 & 0.079 \\
\hline alter $* f r$ & & & & -0.704 & 2.649 & 0.79 \\
\hline separate $* f r$ & -0.596 & 1.694 & 0.725 & -0.75 & 1.779 & 0.673 \\
\hline constant & 83.827 & 30.961 & 0.007 & 99.000 & 25.573 & 0 \\
\hline Sargan (p-value) & & 0.257 & & & 0.2 & \\
\hline $\begin{array}{l}\text { Arellano-Bond (p- } \\
\text { value 1st, } 2 \text { nd Order) }\end{array}$ & 0.000 & 0.608 & & 0.000 & 0.728 & \\
\hline No Observations & & 443 & & & 435 & \\
\hline No Instruments & & 32 & & & 33 & \\
\hline
\end{tabular}

$* 10 \%, * * 5 \%$ and $* * * 1 \%$ signification level. Std. e.: standard errors

As for the control variables, some of them have significant coefficients and with the expected sign. The coefficient of the lagged dependent variable is positive and significant, consistent with Marjit et al. (2014), and the model has good econometric properties, which confirms the hypothesis developed at the beginning of section 4 , so the dynamic character of the model is corroborated. The coefficient of time trend is also significant, avoiding potential unit root 
problems. The coefficient of the logarithm of the GDP per capita has a negative sign, as in Guttman and Richards (2004), in contrast with other authors such as Chang et al. (2009) and Ram (2009), who obtain positive coefficients. Guttman and Richards (2004) suggest that if trade variables are incorporated, as is our case with the variable TOT, the trade openness relationship with income is negative. They explain that, according to the literature, non-traded prices are lower in developing countries, so, based on the assumption that all countries produce the same proportion of traded and non-traded goods, the value of the non-traded goods would be lower in developing than developed countries. Hence, incorporating trading variables, the GDP would be negatively related with trade openness. Another explanation they provide is that the non-traded sector is higher in developed countries. The variable relating to the public surplus, surplus, is a variable of macroeconomic stability, and a positive correlation is obtained with the trade openness rate, as in Aizenman and Noy (2009). Finally, the coefficient of the variable TOT has a negative sign because, as Camagni (2002) states, the terms of trade have a negative correlation with competitiveness. Nonetheless, the coefficient of the terms of trade variable does not appear to be economically significant, due to its low magnitude. The coefficients of all these variables have a significance greater than 5 percent, with the exception of the public surplus variable of Model II, with a significance greater than 10 percent.

In our model, no significance is obtained for the coefficients of the geographical, financial and institutional variables and the variables related with factor endowment or human capital.

The estimated coefficients inform us of the short-term effects of exogenous variables on the endogenous variable. Long-term effects are calculated by dividing the former variables by one minus the coefficient of the lag of the endogenous variable. The elasticities of the short- and long-term effects of the significant variables of Models I and II are summarized in Table 5. This 
table shows that the long-term effects are higher than the short-term effects in absolute terms for all variables.

Table 5. Short- and Long-Term Effects

\begin{tabular}{ccccc}
\hline Model & \multicolumn{2}{c}{ I I } \\
\hline Variable & Short run effect & Long run effect & Short run effect & Long run effect \\
gdppc & -15.420 & -56.325 & -16.438 & -51.853 \\
surplus & 0.784 & 2.863 & 0.684 & 2.156 \\
TOT & $-2.88 \mathrm{E}-13$ & $-1.05196 \mathrm{E}-12$ & $-3.67 \mathrm{E}-13$ & $-1.15767 \mathrm{E}-12$ \\
$f V A T$ & 2.572 & 9.393 & & \\
O2T & & & 2.736 & 8.631 \\
\hline
\end{tabular}

For our interest variables, the long-term effect of financial VAT is 9.39 percent and that of the impact of the $\mathrm{O} 2 \mathrm{~T}$ variable is 8.63 percent. We can therefore assert that financial VAT, and specifically the "option-to-tax" method, seems to contribute to increasing the efficiency of the economy, improving the degree of competitiveness of a country through its rate of trade openness, in the short and especially in the long term.

\section{Concluding Remarks}

We have theoretically and empirically analyzed the effects on trade openness of levying VAT on financial services. Theoretically, we expect financial VAT to reduce the price of traded goods relative to the price of non-traded goods, allowing an increase in the tradable sector. The results obtained in our empirical exercises suggest, first, that financial VAT, and in particular the "option-to-tax" method applied by some countries in the European Union, has a positive impact on a country's rate of trade openness; and second, that the "separate taxes" do not appear to have a significant effect on trade openness. 
Therefore, eliminating the exemption and establishing financial VAT would benefit the economy. The problem is how to apply the levy method. Many methods have been designed, but they are either too simple and do not allow full taxation of the financial services, such as zerorate, or they produce distortions, such as the addition method, or they are theoretically accurate but difficult to apply, such as the cash flow method with TCA ("tax calculation account"). For a discussion of the methods, see López-Laborda and Peña (2017b).

At the mid-point of this trade-off between simplicity and accuracy, in López-Laborda and Peña (2018) we developed a sufficiently precise but feasible method for taxing financial services under VAT. This is the "mobile-ratio" method, which taxes the financial margin of each company using a mobile-ratio approach. The tax base is constructed by applying the same ratio to each interest transaction carried out by the company in a given period: e.g., each loan or deposit interest. The ratio consists of the margin generated by financial services provided by the company (i.e., the difference between interest receipts and interest payments) during the period closest to the current one for which the information is available, divided by the total value of the interests of the company (i.e., interest receipts plus interest payments) in that same period. The VAT rate is then applied to the tax base. Under this method, VAT rate is also directly applied to net explicit fees and commissions. Thus, all the financial value added provided by a company is taxed. Furthermore, the mobile-ratio method is applied to financial services provided by financial and non-financial entities in order to achieve neutrality. 


\section{References}

AIZENMAN, J., and NOY, I. (2009): "Endogenous financial and trade openness", Review of Development Economics, 13(2): 175-189.

ALCALÁ, F. and CICCONE, A. (2004): "Trade and productivity", Quarterly Journal of Economics, 2: 613-646.

ALESINA, A. and WACZIARG, R. (1998): "Openness, country size and government”, Journal of Public Economics, 69: 305-321.

ARELLANO, M. and BOND, S. (1991): "Some tests of specification for panel data: Monte Carlo evidence and an application to employment equations", Review of Economic Studies 58: 277-297.

ARELLANO, M. and BOVER, O. (1995): "Another look at the instrumental variable estimation of error-components models", Journal of Econometrics 68: 29-51.

BENARROCH, M. and PANDEY, M. (2008): "Trade openness and government size", Economics Letters, 101: 157-159.

BENARROCH, M. and PANDEY, M. (2012): "The relationship between trade openness and government size: does disaggregating government expenditure matter?", Journal of Macroeconomics, 34 (1): 239-252.

BENEDEK, D., DE MOOIJ, R.A., KEEN, M. and P. WINGENDER (2019): "Varieties of VAT pass through", International Tax and Public Finance, 1-14.

BENIGNO, G. and FORNARO, L. (2014): "The financial resource curse", The Scandinavian Journal of Economics, 116(1): 58-86.

BLUNDELL, R., and BOND, S. (1998): "Initial conditions and moment restrictions in dynamic panel data models", Journal of Econometrics, 87: 115-143.

BOI (2016): “A Business Guide to Thailand 2016", Thailand Board of Investment (www.boi.go.th/upload/content/BOI-BusinessGuide2016-20160318_87145.pdf).

BURNS, L. (2007): "The Taxation of Financial Services under a VAT in Developing Countries", p.13 (paper presented at the 4th annual Asian Tax Forum, Hanoi, Vietnam, 19-20 April 2007).

CAMAGNI, R. (2002): "On the Concept of Territorial Competitiveness: Sound or Misleading?", Urban Studies, 39(13): 2395-2411.

CHANG, R., KALTANI, L. and LOAYZA, N. V. (2009): "Openness can be good for growth: The role of policy complementarities", Journal of Development Economics, 90: 33-49.

DE LA FERIA, R. and KREVER, R. (2012): "Ending VAT Exemptions: Towards A PostModern VAT", Oxford University Centre for Business Taxation Working Papers, WP12/28. (eureka.bodleian.ox.ac.uk/4387/1/WP1228.pdf). 
DE LA FERIA, R. and WALPOLE, M. (2009): "Options for taxing financial supplies in Value Added Tax: EU vat and Australian GST models compared", International and Comparative Law Quarterly, 58: 897-932.

(www.sbs.ox.ac.uk/sites/default/files/Business_Taxation/Docs/Publications/Working_Papers/Ser ies_08/WP0818.pdf).

DELOITTE (2013): Service Tax in India. A Handbook.

(www.cefi.in/wp-content/uploads/2014/09/Deloitte_Service-Tax-in-India.pdf).

ERNST and YOUNG (2009): "Design and Impact of the "Option to Tax" System for application of VAT to financial services", Report prepared for the European Banking Federation, October 28, 2009.

EUROPEAN COMMISSION (2011): "Impact Assessment Accompanying the Document Proposal for a Council Directive on a Common System of Financial Transaction Tax and Amending Directive 2008/7/EC”, SEC (2011) 1102 final, final Vol. 6 (Annex 5).

Brussels, Belgium.

FELDSTEIN, M. and KRUGMAN, P. R. (1990): "International Trade Effects of Value-Added Taxation”, in E. Assaf Razin and J. Slemrod, eds., Taxation in the Global Economy (pp. 263-282), University of Chicago Press, Chicago.

FREUND, C., and WEINHOLD, D. (2002): “The Internet and international trade in services", American Economic Review, 92(2): 236-240.

GAREN, J. and TRASK, K. (2005): "Do more open economies have bigger governments? Another look", Journal of Development Economics, 77: 533-551.

GILLIS, M. (1987): “The VAT and Financial Services”, World Bank Departmental Working Papers, DRD220.

(documents.worldbank.org/curated/en/514711468740445677/The-VAT-and-financial-services).

GUTTMANN, S., and RICHARDS, A. (2006): "Trade openness: an Australian perspective", Australian Economic Papers, 45(3): 188-203.

HAU, H. (2002): "Real Exchange Rate Volatility and Economic Openness: Theory and Evidence", Journal of Money, Credit and Banking, 34(3): 611-630.

HUIZINGA, H. (2002): “A European VAT on Financial Services?”, Economic Policy, 17(35): 497-534.

JENKINS, G. and KHADKA, R. (1998): “Tax Reform in Singapore”, International Tax Program, (Vol. 644), Harvard Law School, Harvard Institute for International Development, John F. Kennedy School of Government, Harvard University.

JETTER, M. and PARMETER, C. F. (2015): "Trade openness and bigger governments: The role of country size revisited", European Journal of Political Economy, 37: 49-63.

KEEN, M., KRELOVE, R. and NORREGARD, J. (2010): “The Financial Activities Tax", in S. Claessens, M. Keen and C. Pazarbasioglu, eds., Financial Sector Taxation: The IMF's 
Report to the G-20 and Background Material, (pp. 118-143) International Monetary Fund. Washington D.C., United States.

KEEN, M., KRELOVE, R. and NORREGARD, J. (2016): “The Financial Activities Tax”, Canadian Tax Journal, 64(2): 389- 400

KPMG (2016): “China's new VAT rates \& rules - high level policies and general impacts across all industries", China Tax Alert, 9.

(www.kpmg.com/CN/en/IssuesAndInsights/ArticlesPublications/Newsletters/ChinaAlerts/Docu ments/china-tax-alert-09-vat-implementation-rules.pdf).

KRUGMAN, P. R. (1991): Geography and Trade, Cambridge, MA: MIT Press.

LOCKWOOD, B. (2011): "Estimates from national accounts data of the revenue effect of imposing VAT on currently exempt sales of financial services companies in the EU," in , PWC, eds., How the EU VAT exemptions impact the banking sector, Study to assess whether banks enjoy a tax advantage as a result of the EU VAT exemption system (www.pwc.com/gx/en/financial-services/pdf/2011-10-18_vat_study_final_report.pdf)

LÓPEZ-ALASCIO, J.M. (2013): "La opción por la tributación de las operaciones financieras en el IVA”, Cuadernos de Formación, vol. 16/2013, col. 7/13, 125-136, Instituto de Estudios Fiscales.

LÓPEZ-LABORDA, J., and PEÑA, G. (2017a): "Efectos sobre la redistribución de la renta del gravamen de los servicios financieros en el IVA", Working Paper 11, Grupo de Investigación de Economía Pública, Universidad de Zaragoza.

(www.economiapublica.net/wp-content/uploads/2017/06/Redistribución.pdf)

LÓPEZ-LABORDA, J., and PEÑA, G. (2017b): "International Practices of Financial VAT", International VAT Monitor, 28 (6): 457-465.

LÓPEZ-LABORDA, J., and PEÑA, G. (2017c): "Does financial VAT affect the size of the financial sector", Economics: The Open-Access, Open-Assessment E-Journal, 11(20177), 1-28.

LÓPEZ-LABORDA, J., and PEÑA, G. (2018): “A New Method for Applying VAT to Financial Services", National Tax Journal, 71 (1): 155-182.

MARJIT, S., MANDAL, B. and ROY, S. (2014): "Trade Openness, Corruption and Factor Abundance: Evidence from a Dynamic Panel," Review of Development Economics, 18(1): 45-58.

MIROUDOT, S., SAUVAGE, J. and SHEPHERD, B. (2013): "Measuring the cost of international trade in services", World Trade Review, 12(4): 719-735.

MERRILL, P.R. (2011): "VAT Treatment of the Financial Sector", Tax Analysts, 163-185 (www.taxwire.org/www/freefiles.nsf/Files/MERRILL-13.pdf/\$ file/MERRILL-13.pdf). 
MØLLER, H. and HJERRILD B. (2013): "Taxation of the Financial Sector in Denmark", Nordisk Skattevidenskabeligt Forskningsråd, spring, p.93-132 (www.djoefforlag.dk/sites/ntj/files/2013/2013_10.pdf).

MSF (2012): “Korean Taxation”, Ministry of Strategy and Finance, Korea.

(www.nts.go.kr/eng/data/KOREANTAXATION2012.pdf).

NASREEN, S. and ANWAR, S. (2014): "Causal relationship between trade openness, economic growth and energy consumption: A panel data analysis of Asian countries", Energy Policy, 69: 82-91.

OWENS, J. (2014): “Aligning China's Economic and Tax Systems-The Role of China's1994 Tax Reform", Manuscript, WU Global Tax Policy Center at the Institute for Austrian and International Tax Law (Vienna), (www.wu.ac.at/fileadmin/wu/d/i/taxlaw/institute/WU_Global_Tax_Policy_Center/46_Re view_China_1994_Tax_Reform-20141026-NL.pdf).

PHILLIPS, P. C. and PERRON, P. (1988): “Testing for a unit root in time series regression", Biometrika, 75(2): 335-346.

PONS, T. (2006): "Option for Taxation of Financial Services in France”, International VAT Monitor, International Bureau of Fiscal Documentation, May/June 2006, 182-185 (http://www.empcom.gov.in/WriteReadData/UserFiles/file/2006-33.pdf).

PWC (2015): "VAT on Financial Services," On Point, Tax Services, Report of PricewaterhouseCoopers LLP, Ghana, (http://www.pwc.co.za/en/assets/pdf/on-point-vaton-financial-services-3rd-edition.pdf).

RAM, R. (2009): “Openness, country size, and government size: additional evidence from a large cross-country panel," Journal of Public Economics, 93: 213-218.

ROC (2016): "Guide to ROC Taxes 2016”, Ministry of Finance Republic of China (Taiwan).

RODRIK, D. (1998): “Why do more open economies have bigger governments?" Journal of Political Economy, 106(5): 997-1032.

SCHATAN, R. (2003). VAT on banking services: Mexico's experience. International VAT Monitor, 14(4): 287-294. (http://www.empcom.gov.in/WriteReadData/UserFiles/file/2003-17.pdf).

SCHENK, A. (2009): “Taxation of Financial Services (Including Insurance) under a US Value Added Tax." Tax Law Review, 63: 409-442.

SVALERYDA, H. and VLACHOS, J. (2002): "Markets for risk and openness to trade: how are they related?", Journal of International Economics, 57: 369-395.

XU, Y., and KREVER, R. (2016): "Applying VAT to financial services in China: Opportunities for China and lessons for the world?", Australian Tax Review, 45(1): 38-49. 
WINDMEIJER, F. (2005). "A finite sample correction for the variance of linear efficient twostep GMM estimators", Journal of Econometrics 126(1): 25-51, (www.sciencedirect.com/science/article/pii/S0304407604000387).

WORLD BANK (2018): World Bank Open Data, Database

(data.worldbank.org).

ZEE, H. H. (2004): Taxing the Financial Sector: Concepts, Issues, and Practice, Washington, DC, United States: International Monetary Fund.

ZGLO (2006): “Technical Report Policy Review of Financial Sector”, Zambrano \& Gruba Law Office Report, Prepared for the Taxation Capital Market Development Council Republic of the Philippines, 30 June 2006. (pdf.usaid.gov/pdf_docs/Pnadh620.pdf). 